Article

\title{
Storage Stability and Disinfection Performance on Escherichia coli of Electrolyzed Seawater
}

\author{
Regina G. Damalerio ${ }^{1}$, Aileen H. Orbecido ${ }^{1}$, Marigold O. Uba ${ }^{2}$, Patricio Elvin L. Cantiller ${ }^{2}$ and \\ Arnel B. Beltran 1,* \\ 1 Chemical Engineering Department, De La Salle University, Malate, Manila 1004, Philippines; \\ regina_damalerio@dlsu.edu.ph (R.G.D.); aileen.orbecido@dlsu.edu.ph (A.H.O.) \\ 2 Biology Department, De La Salle University, Malate, Manila 1004, Philippines; \\ marigold.uba@dlsu.edu.ph (M.O.U.); patricio.cantiller@dlsu.edu.ph (P.E.L.C.) \\ * Correspondence: arnel.beltran@dlsu.edu.ph; Tel.: +632-524-4611 (local 218)
}

Received: 22 March 2019; Accepted: 24 April 2019; Published: 10 May 2019

\begin{abstract}
The study investigated the effect of storage conditions on the stability of electrolyzed seawater $(\mathrm{ESW})$ 's physicochemical properties $(\mathrm{pH}$, oxidation-reduction potential (ORP), and free chlorine (FC) concentration), and bactericidal efficiency on the fecal coliform Escherichia coli for 30 days. Preliminary experiments were conducted to determine the optimal current and electrolysis time. Two batches of $2750 \mathrm{~mL}$ filtered seawater were electrolyzed using $50 \mathrm{~mm} \times 192 \mathrm{~mm}$ platinum-titanium mesh electrodes at a current of $1.5 \mathrm{~A}$ for $20 \mathrm{~min}$. One hundred milliliters of electrolyzed solution was transferred into each amber glass and high-density polyethylene (HDPE) bottles. The bottles were stored in a dark area at ambient temperature. The results showed an increase in $\mathrm{pH}$ and a decrease in ORP and FC concentration through time. Hypochlorous acid remained as the dominant component since the $\mathrm{pH}$ levels of the solutions remained below 7.5. FC decay was investigated using Chick's Law. It was determined that the decay in HDPE bottles $\left(\mathrm{k}=-0.066\right.$ day $\left.^{-1}\right)$ was faster compared to amber glass bottles $\left(k=-0.046\right.$ day $\left.^{-1}\right)$. Nonetheless, HDPE bottles could still be used as an alternative container for 30 days only due to observed instability beyond 30 days. ESW remained effective since no surviving population of E. coli was observed throughout the experimentation.
\end{abstract}

Keywords: disinfection performance; Escherichia coli; electrolysis; kinetics; storage stability; seawater

\section{Introduction}

Electrochemical disinfection was introduced as an alternative due to its advantages over utilization of chlorine reagents generated from chlorine gas [1-5]. It is performed by passing current through chloride-containing water, which can be made synthetically (brine solution) or collected from a natural source (seawater) [2,6]. The presence of sodium chloride $(\mathrm{NaCl})$ in the solution is important for the formation of oxidizing agents, such as free chlorine (FC), sodium hypochlorite $(\mathrm{NaClO})$, or hypochlorous acid ( $\mathrm{HOCl})[5,7]$. These compounds are responsible for inactivating pathogenic micro-organisms by oxidizing or attacking both the inner and outer membrane of the cell [8-10]. Other advantages of electrochemical disinfection include on-site production, raw material availability, an environment-friendly process, a less-hazardous reaction, low cytotoxicity, and no reported microbial resistance [10]. Furthermore, it has been utilized in several sectors, such as agricultural and food industries, since the disinfectant can be produced over wide $\mathrm{pH}$ ranges [11-15]. Xie et al. [12] investigated the effect of acidic electrolyzed water stored at different temperatures on contaminated raw shrimp, while Kasai et al. [16] investigated the effect of electrolyzed seawater (ESW) in naturally contaminated oysters. Moreover, the disinfectant can be applied in sanitizing materials and equipment. 
Osafune et al. [10] concluded that electrolyzed acidic water is effective as it destroyed the cellular structures of the three bacterial species cultivated from the kendo equipment.

Seawater has $3.5 \%$ salinity, which predominantly consists of sodium and chloride ions. Furthermore, it also contains bromine, which is converted into an oxidant through electrolysis. These oxidizing compounds are detrimental towards pathogenic micro-organisms $[4,14,17,18]$. Thus, ESW has been employed and studied as a disinfectant [9,14,16-19]. However, the main problem lies in its storage stability through time [1,2]. The disinfectant is considered stable when it is still effective for inactivating pathogenic microorganisms. Residual oxidants or FC remains present and dominant, despite the changes in the physicochemical properties and storage conditions. No studies related to storage stability of ESW can be found in the literature since it is more often viewed as an alternative to water disinfection and as a disinfectant to be utilized immediately. Therefore, there is a possibility that the production and utilization of the disinfectant will be maximized by investigating its storage stability through time. The study could benefit people living near coastal areas, where raw material is abundant and accessible. Furthermore, this could serve as temporary alternative solution when sanitation is inaccessible (e.g., calamities).

The storage stability of ESW is determined by investigating the effects of the storage conditions and changes in the physicochemical properties, such as $\mathrm{pH}$, oxidation-reduction potential (ORP), and FC concentration through time, to its bactericidal efficiency on the fecal coliform Escherichia coli. The rate of FC decay in amber glass and high-density polyethylene (HDPE) bottles is investigated using Chick's Law to determine the possibility of using HDPE bottles as an alternative storage container to amber glass bottles.

\section{Materials and Methods}

\subsection{Materials}

Glassware, platinum-titanium mesh electrodes, and reagents, such as $N, N$-dimethyl-pphenylenediamine (DPD) powder, phosphate-buffered saline, nutrient agar, and broth powder, were purchased from several local suppliers. Purified stock culture of E. coli was acquired from the microbiology laboratory. The seawater sample utilized in the experiment was collected five meters away from the beach shore of Oriental Mindoro, Philippines. It was filtered using a PM10 microfilter before being stored at ambient temperature.

\subsection{Electrolysis Setup}

Fifty by $192 \mathrm{~mm}$ titanium-platinum mesh electrodes (mesh size: $10 \times 5 \mathrm{~mm}$; electrode surface area $=23 \mathrm{~cm}^{2}$ ) were sonicated for $30 \mathrm{~min}$ to remove unwanted particles on the surface $[18,19]$, and submerged vertically with a $0.5 \mathrm{~cm}$ gap in a $4 \mathrm{~L}$ Pyrex beaker. An alternating current (AC) power supply was utilized as an electrical source (Figure 1). Twenty each of $120 \mathrm{~mL}$ amber glass bottles and $250 \mathrm{~mL}$ HDPE bottles were cleaned and labeled prior to the day of the electrolysis experiment. 


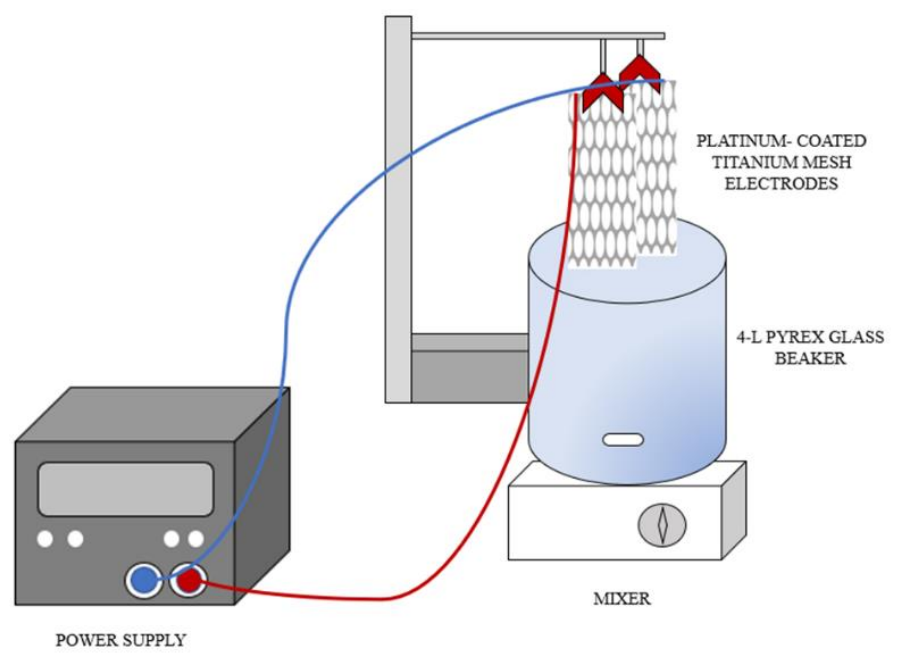

Figure 1. Electrolysis Setup.

\subsection{Electrolysis of Seawater}

Two batches of $2750 \mathrm{~mL}$ seawater were electrolyzed at a current of $1.5 \mathrm{~A}$ for $20 \mathrm{~min}$. The applied current and electrolysis time were determined based on preliminary electrolysis experiments. It was carried out by investigating the effects of varying current and electrolysis duration on the physicochemical properties of ESW.

\subsection{Storage Experiment}

About $100 \mathrm{~mL}$ of ESW was transferred into each amber glass and HDPE bottle. Bottles were stored in a dark place at ambient temperature. The physicochemical properties and bactericidal efficiency of ESW were evaluated for 30 days.

\subsection{Preparation of the Working Culture of E. coli}

A purified stock culture of $E$. coli was cultivated every two weeks with nutrient agar and maintained at $4-10{ }^{\circ} \mathrm{C}$ for the duration of the study. A working bacterial suspension, prepared from the stock culture, was standardized prior to every disinfection experiment. This was performed by inoculating fresh colonies of E. coli in sterile distilled water until the turbidity was adjusted to equal McFarland Standard \#0.5, which approximates $1.5 \times 10^{8}$ colony forming units (CFU) per mL [20]. A standard plate count was also performed to confirm the microbial density of the standardized turbidity $[1,2]$.

\subsection{Disinfection Experiments}

To determine the effect of ESW on E. coli, $1 \mathrm{~mL}$ of the standardized E. coli suspension was mixed with and exposed to $9 \mathrm{~mL}$ ESW for one minute. Then, $1 \mathrm{~mL}$ of the latter mixture was added to $9 \mathrm{~mL}$ of Phosphate-Buffered Saline for one minute to render the ESW ineffective. A 10-fold serial dilution was performed by adding $1 \mathrm{~mL}$ from the previous tube to $9 \mathrm{~mL}$ of sterile distilled water up to $10^{-3}$ dilution. Using the spread plate technique, $0.1 \mathrm{~mL}$ aliquot from each solution was inoculated on nutrient agar plates. These were performed in duplicates. After incubation at $37^{\circ} \mathrm{C}$ for $18-24$ hours [1,2], the plates were examined for growth and the $\mathrm{CFU} / \mathrm{mL}$ of $E$. coli was determined.

\subsection{Electrolysis Setup}

The $\mathrm{pH}$ and ORP values were measured using a pocket $\mathrm{pH}$ meter (Lutron, $\mathrm{PH}-211$ ) and an ORP meter (Lutron, ORP-213; $\mathrm{Ag} / \mathrm{AgCl}$ reference electrode), and ranged from $\mathrm{pH} 0.00$ to 14.00 and ORP $0.0 \pm 1000.0 \mathrm{mV}$, respectively. The $\mathrm{pH}$ meter was calibrated using standard buffers at a $\mathrm{pH}$ of 4.0, 7.0, and 10.0. The $\mathrm{N}, \mathrm{N}$-dimethyl-p-phenylenediamine (DPD) colorimetric method employing a UV/Vis Spectrophotometer at a wavelength of $515 \mathrm{~nm}$ was used to determine the FC concentration [1]. 


\section{Theoretical Framework}

Due to limited literature data, the system is assumed to contain sodium chloride only. Equations (1-6) below show reactions occurring at the anode and cathode sides during electrolysis. Water and chloride ions at the anode are oxidized to oxygen, hydrogen ions, and gaseous chlorine, while water at the cathode is reduced to hydroxides and hydrogen gas. The evolution of chlorine becomes more favorable than oxygen at the anode side due to the increase in hydrogen ion concentration in the solution [6].

Anode Side

$$
\begin{array}{cc}
2 \mathrm{H}_{2} \mathrm{O} \rightarrow \mathrm{O}_{2}+4 \mathrm{H}^{+}+4 \mathrm{e}^{-} & \mathrm{E}_{\mathrm{O}}=1.23 \mathrm{~V} \\
2 \mathrm{Cl}^{-} \leftrightarrow 2 \mathrm{e}^{-}+\mathrm{Cl}_{2}(\mathrm{~g}) & \mathrm{E}_{\mathrm{O}}=1.36 \mathrm{~V}
\end{array}
$$

Cathode Side

$$
2 \mathrm{H}_{2} \mathrm{O}+2 \mathrm{e}^{-} \rightarrow 2 \mathrm{OH}^{-}+\mathrm{H}_{2} \quad \mathrm{E}_{\mathrm{O}}=-0.83 \mathrm{~V}
$$

Aqueous chlorine formed from gaseous chlorine partially dissociates to hypochlorous acid and chloride and hydrogen ions at increasing concentrations. A further increase in the concentration of hypochlorous acid would result in its decomposition to hypochlorite and hydrogen ions.

$$
\begin{gathered}
\mathrm{Cl}_{2(\mathrm{aq})}+\mathrm{H}_{2} \mathrm{O} \leftrightarrow \mathrm{HOCl}+\mathrm{Cl}^{-}+\mathrm{H}^{+} \quad \mathrm{K}_{\mathrm{H}}=4.0 \times 10^{-4} \text { at } 25^{\circ} \mathrm{C} \\
\mathrm{HOCl} \leftrightarrow \mathrm{OCl}^{-}+\mathrm{H}^{+} \quad \mathrm{K}_{\mathrm{H}}=3.0 \times 10^{-8} \text { at } 25^{\circ} \mathrm{C}
\end{gathered}
$$

The distribution of chlorine species can be determined from Equations (4) and (5) by expressing it as equilibrium expressions. Simplifying these expressions would result in two equations as functions of $\mathrm{pH}$ and/or chloride concentration. Equation 6 determines the ratio of aqueous chlorine to hypochlorous acid, while Equation (7) determines the ratio of hypochlorous acid to hypochlorite [1,21].

$$
\begin{gathered}
\frac{\left[\mathrm{Cl}_{2(\mathrm{aq})}\right]}{[\mathrm{HOCl}]}=10^{\mathrm{pK}_{\mathrm{H}}-\mathrm{pH}+\log \mathrm{Cl}^{-}} \\
\frac{\left[\mathrm{OCl}^{-}\right]}{[\mathrm{HOCl}]}=10^{\mathrm{pH}+\mathrm{pKa}}
\end{gathered}
$$

The distribution of aqueous chlorine, hypochlorous acid, and hypochlorite ions is plotted in Figure 2. It is observed that aqueous chlorine is present in highly acidic conditions and decreases beyond $\mathrm{pH}$ 2.0. The concentration in an ideal system decreases as it approaches $\mathrm{pH} 4.0$ and hypochlorous acid dominates the region beyond $\mathrm{pH}$ 4.0. Hypochlorous acid is the most important component for ESW due to its high oxidizing property, which is responsible for inactivating pathogenic micro-organisms [8]. Furthermore, it is more stable than aqueous chlorine due to its less volatile nature [1,22]. Hypochlorous acid decreases gradually due to its weak acidic nature and remains predominant until $\mathrm{pH} 7.5$, as illustrated in Figure 2b. Beyond pH 7.5, hypochlorite ions become the predominant component of the solution. 


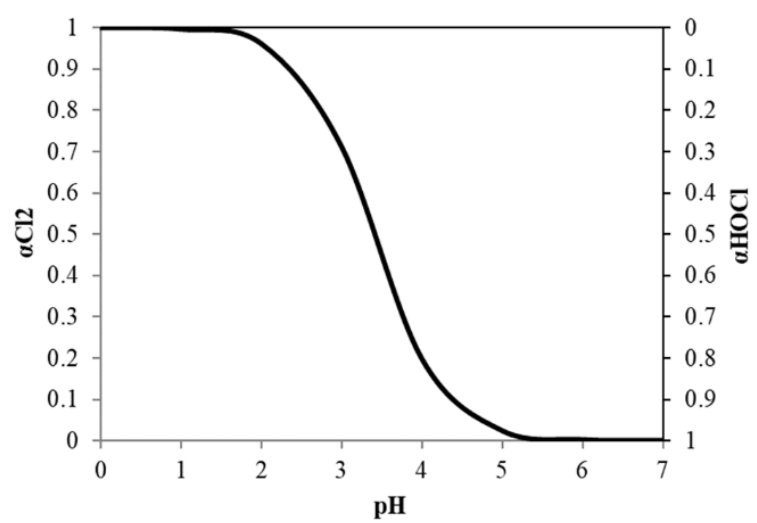

(a)

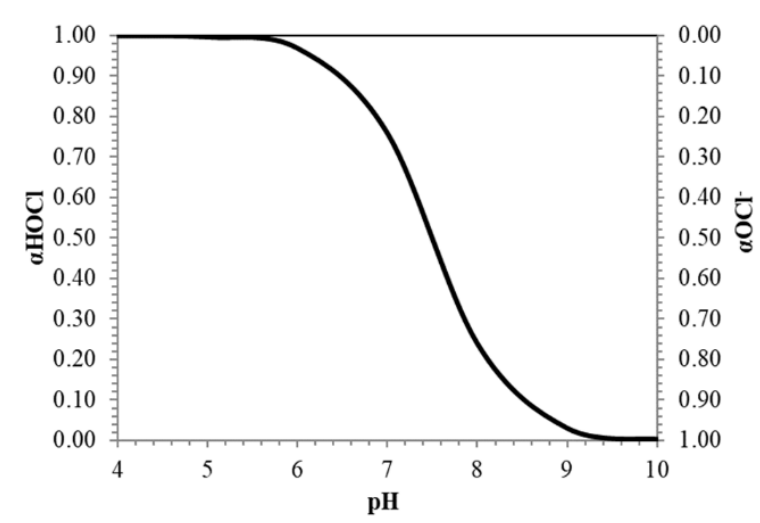

(b)

Figure 2. Distribution of (a) aqueous chlorine; and (b) hypochlorous acid in electrolyzed seawater (ESW) at different $\mathrm{pH}$ levels.

\section{Results and Discussion}

\subsection{Electrolysis Parameter Selection}

The preliminary experiments aided in determining the behavior of the physicochemical properties during the electrolysis of the seawater sample. It defined the relationship of the three properties and the effect of increasing applied current to the system through time. Figure 3a shows the decrease of $\mathrm{pH}$ at increasing electrolysis time and applied current. ESW becomes more acidic as the current increases due to continuous generation of hydrogen $\left(\mathrm{H}^{+}\right)$ions. At the end of the electrolysis, the $\mathrm{pH}$ of ESW at $0.5 \mathrm{~A}, 1.0 \mathrm{~A}$, and $1.5 \mathrm{~A}$ reached values of $5.76,3.77$, and 3.35 , respectively.



(a)

Figure 3. Cont. 




(b)

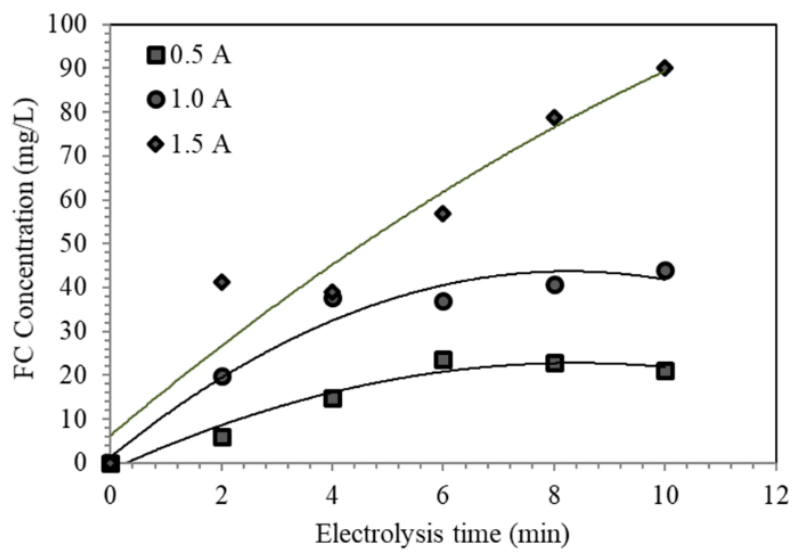

(c)

Figure 3. Preliminary results of ten minutes of ESW conducted at $0.5 \mathrm{~A}, 1.0 \mathrm{~A}$, and $1.5 \mathrm{~A}$ for the following physicochemical properties: (a) $\mathrm{pH}$; (b) oxidation-reduction potential (ORP); and (c) free chlorine (FC) concentration.

An increase in the acidity of the solution correlates to an increasing amount of oxidizing compounds, such as aqueous chlorine and hypochlorous acid, in the solution. Thus, high values of ORP and FC concentration are expected $[1,2,12,13,18]$. However, stability in ORP was observed from six minutes onwards at all currents, while stability in FC concentration was achieved from six minutes onwards at currents of $0.5 \mathrm{~A}$ and $1.0 \mathrm{~A}$ (Figure $3 \mathrm{~b}-\mathrm{c}$ ). The stability of the FC concentration could mean that the maximum concentration of hypochlorous acid was attained at a given current. Based on Figure 2, electrolyzed solutions generated at currents of $0.5 \mathrm{~A}$ and $1.0 \mathrm{~A}$ fall in the region where hypochlorous acid is the predominant component. There would be minimal changes in the chlorine species due to a low concentration of aqueous chlorine and slow dissociation of hypochlorous acid to hypochlorite ions. The electrolyzed solutions at 1.5 A predominantly contain aqueous chlorine. Due to its volatile nature, some of the aqueous chlorine could have dissociated to hypochlorous acid to achieve equilibrium, as stated in Equation (6).

From the preliminary results, the current $1.5 \mathrm{~A}$ was utilized to determine the maximum electrolysis time to be used for the actual experimentation. Two runs of electrolysis were conducted and samples were collected every five minutes for evaluation of physicochemical properties. It is shown in Figure 4 that stability was achieved at an electrolysis time of $20 \mathrm{~min}(\mathrm{pH}=4.54, \mathrm{ORP}=988 \mathrm{mV}, \mathrm{FC}=48.97 \mathrm{mg} / \mathrm{L}$ $\mathrm{Cl}_{2}$ ). ESW generated at 20 min was determined to contain a maximum of $86.47 \%$ hypochlorous acid. 


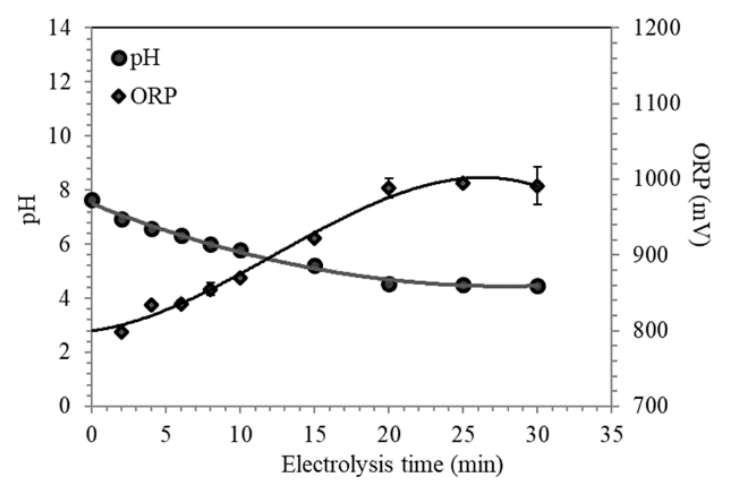

(a)

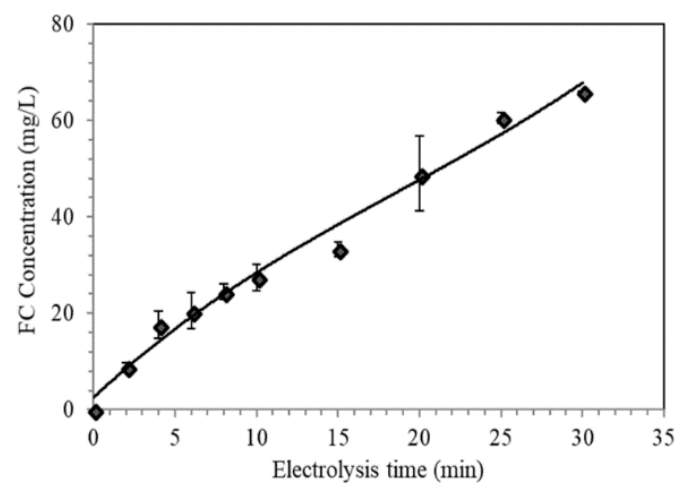

(b)

Figure 4. Behavior of (a) pH and ORP; and (b) FC concentrations at $1.5 \mathrm{~A}$ for 30 min of electrolysis.

The power required for ESW generated at a current of $1.5 \mathrm{~A}$ for $20 \mathrm{~min}$ was determined using the formula [4]:

$$
P=V \times I
$$

where:

$P$ : Power requirement, watts

$V$ : Observed voltage, volts

I: Current applied, ampere

The energy consumption can be calculated by multiplying the calculated power and electrolysis time [4]:

$$
E=P \times t=V \times I \times t
$$

where:

E: Energy consumption, watt-hour

$P$ : Power requirement, watts

$V$ : Observed voltage, volts

I: Current applied, ampere

$t$ : Electrolysis time, hours

The calculated power required for generating one liter of ESW is 2.62 watts. If the system is upscaled to produce 1 kiloliter of the disinfectant, the power requirement is about 2620 watts $(2.62 \mathrm{~kW})$. On the other hand, the energy consumption of 1 kiloliter of electrolyzed seawater is about 873 watt-hours.

\subsection{Storage Effect on Physicochemical Properties}

\subsubsection{Evaluation for 30 Days}

Figure 5 illustrates the behavior of $\mathrm{pH}$ and ORP of stored ESW in amber glass and HDPE bottles throughout the 30-day storage. Initially, the ESW in amber bottles $(\mathrm{pH}=4.21, \mathrm{ORP}=1010 \mathrm{mV})$ contained 83.71\% hypochlorous acid, while the ESW in HDPE bottles $(\mathrm{pH}=5.74, \mathrm{ORP}=920 \mathrm{mV})$ contained $96.86 \%$ hypochlorous acid. It can be observed that there is a gradual increase in $\mathrm{pH}$ and a decrease in ORP throughout the storage period. Slow changes in $\mathrm{pH}$ and ORP could be attributed to the nature of the acid and storage conditions that minimized decomposition of hypochlorous acid through time. 




Figure 5. The $\mathrm{pH}$ and ORP distribution of ESW stored in both bottles throughout the 30-day storage period.

An average $\mathrm{pH}$ of 6.53 was measured for 30-day old solutions stored in both bottles. There was a $2.39 \%$ increase of hypochlorous acid in amber glass bottles and an $11.51 \%$ decrease in HDPE bottles. The increase of the hypochlorous acid in amber glass bottles may be attributed to partial dissociation of remaining aqueous chlorine. On the other hand, the decrease of ORP from 845.50 to $833 \mathrm{mV}$, for both bottles, could be due to the increasing decomposition of hypochlorous acid [1].

The average initial FC concentrations of ESW are $51.85 \mathrm{mg} / \mathrm{L}$ for amber glass bottles and $51.23 \mathrm{mg} / \mathrm{L}$ for HDPE bottles (Figure 6). Unlike in $\mathrm{pH}$ and ORP, FC in both bottles experienced an exponential decline through time. By day 30 , approximately $22.72 \%$ and $8.80 \%$ of the initial FC concentration remained in amber glass and HDPE bottles, respectively.

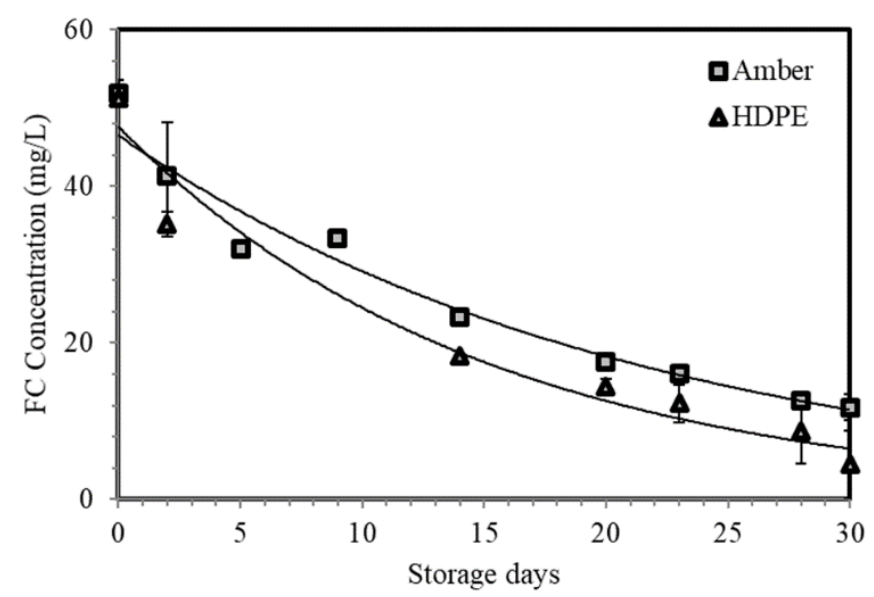

Figure 6. FC distribution of ESW stored in both bottles throughout the 30-day storage period.

The rate of FC decay of ESW during storage can be evaluated using Equation $(10)[1,13]$.

$$
\ln \frac{C_{t}}{C_{o}}=-k t
$$

where:

$C_{t}:$ FC concentration at any storage period $t, \mathrm{mg} / \mathrm{L}$

$C_{o}$ : Initial FC concentration, $\mathrm{mg} / \mathrm{L}$

$k$ : Rate of FC decay, day ${ }^{-1}$

$t$ : Storage period of ESW, day 
The results are illustrated in Figure 7, and it is determined that stored ESW samples experienced single-stage first-order decay due to $\mathrm{HOCl}$ decomposition. The first-order decay was also observed in other studies [1,13,22]. Stored samples in amber glass bottles exhibited slower FC decay $\left(\mathrm{k}=-0.046 \mathrm{day}^{-1}\right)$, compared to stored samples in HDPE bottles $\left(\mathrm{k}=-0.066\right.$ day $\left.^{-1}\right)$. Nonetheless, HDPE bottles could be used as a storage container due to the minimal difference between the two decay constants.

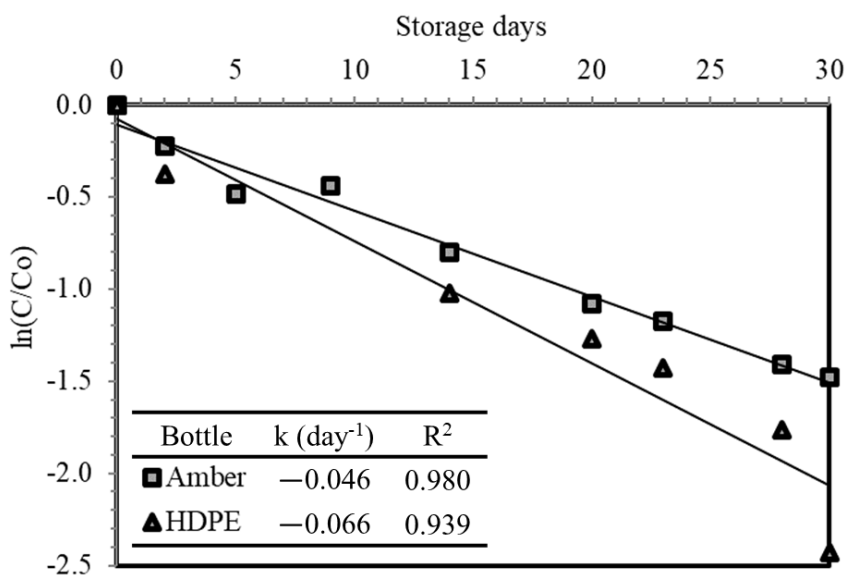

Figure 7. FC decay during the 30-day storage period.

\subsubsection{Extension of 30-Day Storage Evaluation}

The storage experiment was extended for two weeks to gather more information on the effect of storage conditions on the stability and disinfection performance. The remaining ESW in the 28-day-old bottles was used to evaluate the properties and bactericidal efficiency on days 42 and 49. From Table 1, it can be observed that there are minimal changes in the $\mathrm{pH}$ for both bottles. The oxidation-reduction potential of stored ESW in HDPE bottles had a minimal difference between days 28 and 42 but decreased suddenly to $632 \mathrm{mV}$ by day 49. Meanwhile, FC in both bottles continued to decline until it reached less than $5 \mathrm{mg} / \mathrm{L}$. The reason for the decrease in ORP and FC may be attributed to a decrease of hypochlorous acid and escape of chlorine gas through repeated opening of the bottles.

Table 1. pH, ORP, and FC concentration of ESW stored in both bottles at days $0,28,42$, and 49.

\begin{tabular}{ccccc}
\hline Container Type & Days & pH & ORP (mV) & $\begin{array}{c}\text { Free Chlorine } \\
\text { Concentration }(\mathbf{m g} / \mathbf{L})\end{array}$ \\
\hline Amber Glass & 0 & 4.21 & 1010 & 51.85 \\
& 28 & 6.70 & 853.50 & 12.67 \\
& 42 & 6.61 & 855 & 5.17 \\
High-Density Polyethylene (HDPE) & 49 & 6.71 & 815.50 & 2.95 \\
& 0 & 5.74 & 925 & 51.23 \\
& 28 & 7.24 & 797 & 8.77 \\
& 42 & 7.26 & 788.50 & 2.93 \\
\hline
\end{tabular}

\subsection{Storage Effect on Disinfection Performance}

The storage effect on the bactericidal efficiency of ESW on the fecal coliform E. coli was observed for 49 days. The freshly generated solution achieved complete inactivation of $1.5 \times 10^{8} \mathrm{CFU} / \mathrm{mL}$ of $E$. coli due to its slightly acidic $(\mathrm{pH}<6.00)$ and highly oxidizing nature $(\mathrm{ORP}>900 \mathrm{mV})$. It was hypothesized that the effectiveness of the disinfectant would decline through time due to changes in the physicochemical properties. However, no growth was detected for both bottles. A similar result was observed in another study where no surviving population was detected for 30 days, using acidic 
and neutral electrolyzed water on Salmonella typhii and Escherichia coli O157:H7 [2]. The main reason for this result could lie in the amount of hypochlorous acid present. Slow changes were observed throughout storage for ESW both in amber glass and HDPE bottles. From an initial solution containing $83.71 \%$ hypochlorous acid in amber glass bottles and $96.86 \%$ in HDPE bottles, the hypochlorous acid in 30 -day-old solutions became $85.71 \%$. The amount of hypochlorous acid is still high, and this could be enough to inactivate an average initial population of $1.5 \times 10^{8} \mathrm{CFU} / \mathrm{mL}$. The 49 -day-old ESW solutions have neutral $\mathrm{pH}$ and a lower oxidation-reduction potential (ORP $=815.5 \mathrm{mV}$ for amber glass and ORP $=632 \mathrm{mV}$ for HDPE bottles). Despite the low and almost negligible FC concentration, hypochlorous acid remains predominant for stored ESW in both bottles, since the $\mathrm{pH}$ of the solution is still below $7.5[1,2,8]$.

\section{Conclusions}

The changes in the physicochemical properties affect the distribution of chlorine species in ESW stored in both amber glass and HDPE bottles. The increase in $\mathrm{pH}$ and decrease in ORP and FC concentration are due to a decreasing amount of hypochlorous acid through time. Equation (10) was used to investigate the FC decay of ESW through time. Therefore, it was observed that the decline was faster in HDPE bottles $\left(k=-0.066\right.$ day $\left.^{-1}\right)$, compared to amber glass bottles $\left(k=-0.046\right.$ day $\left.^{-1}\right)$. Further investigation revealed that instability in the physicochemical properties occurred in 49-day-old solutions stored in HDPE bottles. However, it did not affect the effectiveness of ESW as a disinfectant for the fecal coliform E. coli. No surviving population of E. coli was observed throughout the experimentation, and this could be due to the predominance of hypochlorous acid in the solution. Based on the results, the use of HDPE bottles for storage is recommended for 30 days only. Further investigation is needed for a full understanding on ESW's storage stability. The physicochemical properties and bactericidal efficiency may be evaluated by changing the storage conditions, such as storage time, temperature, and exposure to light and atmosphere. The antimicrobial assay can also be modified using different microbial species.

Author Contributions: All authors collaborated on this work. Conceptualization, A.B.B.; and R.G.D.; methodology, A.B.B.; R.G.D.; P.E.L.C.; and M.O.U.; formal analysis, A.H.O.; A.B.B.; M.O.U.; P.E.L.C.; and R.D; investigation, R.G.D.; writing—original draft preparation, R.G.D.; writing—review and editing, A.H.O.; A.B.B.; M.O.U.; P.E.L.C.; and R.G.D.; supervision, P.E.L.C.; and M.O.U.

Funding: This research was funded by the University Research Coordination Center of De La Salle University-Manila, grant number 56 N 3TAY 14-3TAY 15.

Acknowledgments: The authors would like to acknowledge the technical staff of the Microbiology Laboratory for their kind assistance and support.

Conflicts of Interest: The authors declare no conflict of interest.

\section{References}

1. Nisola, G.M.; Yang, X.; Cho, E.; Han, M.; Lee, C.; Chung, W.-J. Disinfection Performances of Stored Acidic and Neutral Electrolyzed Waters Generated from Brine Solution. J. Environ. Sci. Health Part A 2011, 46, 263-270. [CrossRef] [PubMed]

2. Cui, X.; Shang, Y.; Shi, Z.; Xin, H.; Cao, W. Physicochemical Properties and Bactericidal Efficiency of Neutral and Acidic Electrolyzed Water under Different Storage Conditions. J. Food Eng. 2009, 91, 582-586. [CrossRef]

3. Diao, H.F.; Li, X.Y.; Gu, J.D.; Shi, H.C.; Xie, Z.M. Electron Microscopic Investigation of the Bactericidal Action of Electrochemical Disinfection in Comparison with Chlorination, Ozonation and Fenton Reaction. Process Biochem. 2004, 39, 1421-1426. [CrossRef]

4. Jung, Y.; Yoon, Y.; Kwon, M.; Roh, S.; Hwang, T.-M.; Kang, J.-W. Evaluation of Energy Consumption for Effective Seawater Electrolysis Based on the Electrodes and Salinity. Desalin. Water Treat. 2015, 57, 10136-10145. [CrossRef]

5. Jeong, J.; Kim, C.; Yoon, J. The Effect of Electrode Material on the Generation of Oxidants and Microbial Inactivation in the Electrochemical Disinfection Processes. Water Res. 2009, 43, 895-901. [CrossRef] 
6. Bennett, J.E. Electrodes for Generation of Hydrogen and Oxygen from Seawater. Int. J. Hydrog. Energy 1980, 5, 401-408. [CrossRef]

7. Hendricks, D. Fundamentals of Water Treatment Unit Processes: Physical, Chemical, and Biological; CRC Press: Boca Raton, FL, USA, 2016.

8. Fukuzaki, S. Mechanisms of Actions of Sodium Hypochlorite in Cleaning and Disinfection Processes. Biocontrol Sci. 2006, 11, 147-157. [CrossRef] [PubMed]

9. Jorquera, M.A.; Valencia, G.; Eguchi, M.; Katayose, M.; Riquelme, C. Disinfection of Seawater for Hatchery Aquaculture Systems Using Electrolytic Water Treatment. Aquaculture 2002, 207, 213-224. [CrossRef]

10. Osafune, T.; Ehara, T.; Ito, T. Electron Microscopic Studies on Bactericidal Effects of Electrolyzed Acidic Water on Bacteria Derived from Kendo Protective Equipment. Environ. Health Prev. Med. 2006, 11, $206-214$. [CrossRef] [PubMed]

11. Gómez-López, V.M.; Gil, M.I.; Pupunat, L.; Allende, A. Cross-Contamination of Escherichia Coli O157: H7 Is Inhibited by Electrolyzed Water Combined with Salt under Dynamic Conditions of Increasing Organic Matter. Food Microbiol. 2015, 46, 471-478. [CrossRef] [PubMed]

12. Xie, J.; Sun, X.H.; Pan, Y.J.; Zhao, Y. Physicochemical Properties and Bactericidal Activities of Acidic Electrolyzed Water Used or Stored at Different Temperatures on Shrimp. Food Res. Int. 2012, 47, 331-336. [CrossRef]

13. Li, J.; Lin, T.; Lu, Q.; Wang, J.J.; Liao, C.; Pan, Y.; Zhao, Y. Changes in Physicochemical Properties and Bactericidal Efficiency of Acidic Electrolyzed Water Ice and Available Chlorine Decay Kinetics during Storage. LWT Food Sci. Technol. 2014, 59, 43-48. [CrossRef]

14. Katayose, M.; Yoshida, K.; Achiwa, N.; Eguchi, M. Safety of Electrolyzed Seawater for Use in Aquaculture. Aquaculture 2007, 264, 119-129. [CrossRef]

15. Graça, A.; Santo, D.; Quintas, C.; Nunes, C. Growth of Escherichia Coli, Salmonella Enterica and Listeria Spp., and Their Inactivation Using Ultraviolet Energy and Electrolyzed Water, on 'Rocha' Fresh-Cut Pears. Food Control 2017, 77, 41-49. [CrossRef]

16. Kasai, H.; Kawana, K.; Labaiden, M.; Namba, K.; Yoshimizu, M. Elimination of Escherichia coli from Oysters Using Electrolyzed Seawater. Aquaculture 2011, 319, 315-318. [CrossRef]

17. Kasai, H.; Watanabe, K.; Yoshimizu, M. Disinfectant Effects of Hypochlorite Produced by Batch Electrolytic System on Fish Pathogenic Bacteria and Virus. Suisanzoshoku 2001, 49, $237-241$.

18. Oh, B.S.; Oh, S.G.; Hwang, Y.Y.; Yu, H.W.; Kang, J.W.; Kim, I.S. Formation of Hazardous Inorganic By-Products during Electrolysis of Seawater as a Disinfection Process for Desalination. Sci. Total Environ. 2010, 408, 5958-5965. [CrossRef] [PubMed]

19. Oh, B.S.; Oh, S.-G.; Jung, Y.J.; Hwang, Y.-Y.; Kang, J.-W.; Kim, I.S. Evaluation of a Seawater Electrolysis Process Considering Formation of Free Chlorine and Perchlorate. Desalin. Water Treat. 2010, 18, 245-250. [CrossRef]

20. Dalynn Biologicals. Available online: http://www.dalynn.com/dyn/ck_assets/files/tech/TM53.pdf (accessed on 16 April 2019).

21. Sincero, A.P.; Sincero, G.A. Physical-Chemical Treatment of Water and Wastewater; CRC Press: Boca Raton, FL, USA, 2002.

22. Len, S.-V.; Hung, Y.-C.; Chung, D.; Anderson, J.L.; Erickson, M.C.; Morita, K. Effects of Storage Conditions and $\mathrm{pH}$ on Chlorine Loss in Electrolyzed Oxidizing (EO) Water. J. Agric. Food Chem. 2002, 50, $209-212$. [CrossRef] [PubMed]

(C) 2019 by the authors. Licensee MDPI, Basel, Switzerland. This article is an open access article distributed under the terms and conditions of the Creative Commons Attribution (CC BY) license (http://creativecommons.org/licenses/by/4.0/). 